\title{
Open Learning Systems for Learners with Capabilities as Innovators at State University of Malang
}

\author{
Henry Praherdhiono, Sulton, AJE Toen Lioe \\ Educational Technology Department \\ Universitas Negeri Malang \\ Malang, Indonesia \\ henry.praherdhiono.fip@um.ac.id
}

\author{
Jihad Hammad \\ Al-quds Open University \\ Palestine
}

\begin{abstract}
Development of learning system in the network with the involvement of Massive Open Online Program (MOOCs) at the State University of Malang, is a priority scale. The open system is the fastest step in developing student's ability to innovate. The study provides an analytical note 1) who the students of Malang State University are and how they have the integrity of an innovator after using the technology, 2) the online learning ecology blended at State University Malang. The first stage of the analysis of MOOCs was done by making a survey of three student forces with six research classes. The second phase of ecology learning development was done through the website. The result was the development of MOOCs accelerated the emergence of contributor ideas so that the learners were facilitated to develop their ability to innovate.
\end{abstract}

Keywords-learning ecology, MOOCs, innovate learner

\section{INTRODUCTION}

Renewal of educational technology has become an agenda at Universitas Negeri Malang/State University of Malang. The innovations have adopted some technologies as in the early 90 s by using email for learning, University LMS in 2009, online long distance education in the mid-2015, and it raised in 2016. The technology in various studies contributes to learning [1][3]. This article presented some of the latest findings from the Massive Open Online Program (MOOCs), and reflections on the changing environment of rapidly changing learning.

Life-based learning in the curriculum will be used by UM to improve student's capability. Learn is not only to work alone and not limited by time [4]. Life-based learning explains that the learning environment can be a source of learning, thus allowing learners' abilities and capabilities [5], [6]. In today's life, whenever and wherever people can learn. Learning is a fundamental need of every human being [7]-[9].

The technology that makes it possible to build a learning environment in Life-based learning is MOOCs. The flexibility of the IT fusion system in learning using MOOCs [3], [10] needs to be developed by the UM to meet the learning needs. By macro, scientific interconnected with each other has even evolved towards transdisciplinary [11]-[13]. The open and integrated learning management system is a real cloud computing enabling students, faculty, managers, and the other users, in the learning age to be a learning entity. The dichotomy of science teaching and learners is almost nonexistent. Everyone shares and learns with various devices [11], [14], [15]. Integration is a solution to the fulfillment and enrichment of resources, media, strategies, assessment, evaluation and the other learning components. UM needs to build a policy in the learning age that is consistent and continuous to develop a transdisciplinary learning environment with IT Fusion system through a safe, convenient, high-quality and meaningful lifebased learning management system.

MOOCs are the developments that serve as a benchmark for modern learning services. In general, research reasons only offer MOOC advantage in terms of ease, affordability and flexibility of learning access [16]-[21]. But in MOOCs research at the State University of Malang this time, to see the needs of MOOCs technology as an additional Learning Object on Learning Management System. The result of the research is a solution for UM to construct learners to have the capability as an innovator.

\section{RESEARCH METHOD}

The research was conducted by doing needs analysis through the data mining management on survey conducted on 180 students randomly at UM. The research instrument used was a questionnaire distributed by online. Master plan to learning network system is a strategic step in accommodating student activity in learning. The methods were performed to see the needs of students and the results of support network system development of UM shown at Fig. 1. The survey of content development was based on The Learning University philosophy of Lifelong education and lifelong learning, in essence, human beings are entitled to education and lifelong learning. 


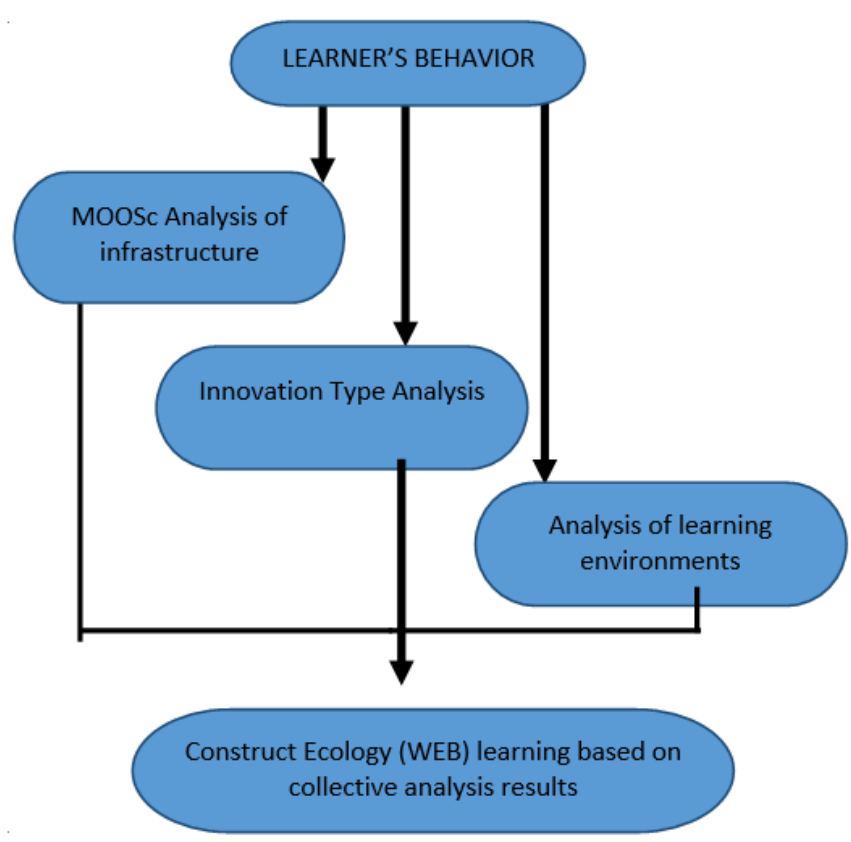

Fig. 1. MOOCs Development Model

In accordance with the concept, all academicians at UM, lecturers, students, administrative staff, and technicians are subjects of learning and learning resources that must continuously learn to support the implementation of their daily tasks through an integrated learning system.

\section{RESULTS AND DISCUSSION}

\section{A. Learner's Behavior}

The students of State University of Malang from generation to generation have differences. These differences are based on the generation patterns [22]-[24]. Each generation has differences with respect to attitudes, work habits, and motivations and the others [25], [26].

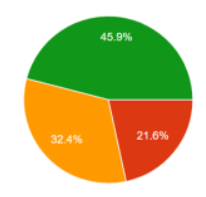

smartphone

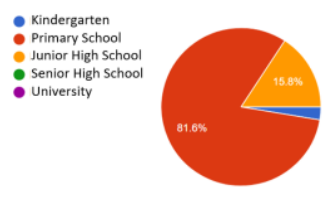

PC's
Fig. 2. Survey Data of the New Student Group

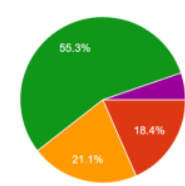

smartphone
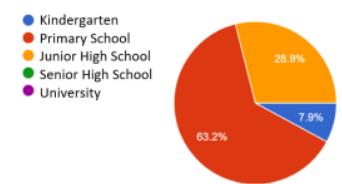

PC's

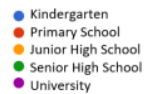
- University

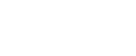

Fig. 3. Survey Data of the Middle Student Group

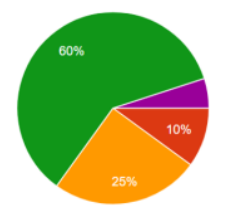

smartphone

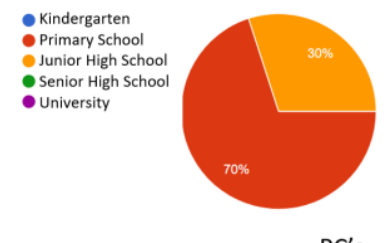

PC's
Fig. 4. Survey Data of the Final Student Group

State University of Malang must understand how to manage generation from time to time. It institutionally also must realize that the difference of generation is regarding knowledge, attitude and skill to use technology. It is impossible for $U M$ to make assumptions of each individual, without having to pay attention to generational groups from time to time in the chronological order [23], [27], [28]. From the results of the survey data processed, the $\mathrm{Z}$ generation that also exists in $U M$ has a good technology literacy and this case is in line with various studies (Fig. 2, Fig. 3, and Fig. 4). It is also important to note that generating thoughts and reviews on generations can be comprehensively obtained by understanding the differences in knowledge and attitudes toward the professions desired by each generation, as well as relating to the socioeconomic status of each generation of students in $U M$.

Research on the students of $U M$ is an issue of character development. The strategic step that is necessary to be initiated is mapping the character of learners based on the general nature of each generation. Referring to humanist research [29].

This study was conducted by looking at the capability model with a survey of organizing capabilities as an Innovator [30]. Q1 asked 120 respondents: Are you constantly looking for new ideas, Q2 with the question: Do you constantly want to find new ways to do activities?, Q3 with the question: Are you constantly getting lots of new ideas and want to know him?, and Q4 with the question: Do you want to be the first one (in your community) with new ideas or new concepts? (Fig. 5). These questions were asked to know how often the behave as a character of innovators [30].

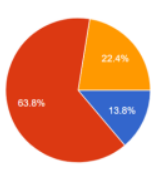

Q1

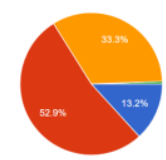

Q3
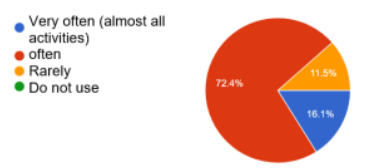

Q2

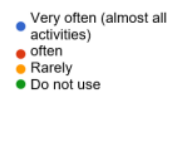

- Kindergarten - Junior High Schoo - Senior High S

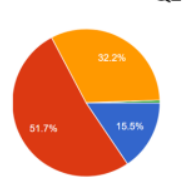

Q4
Fig. 5. Mapping Results of Innovator Character 

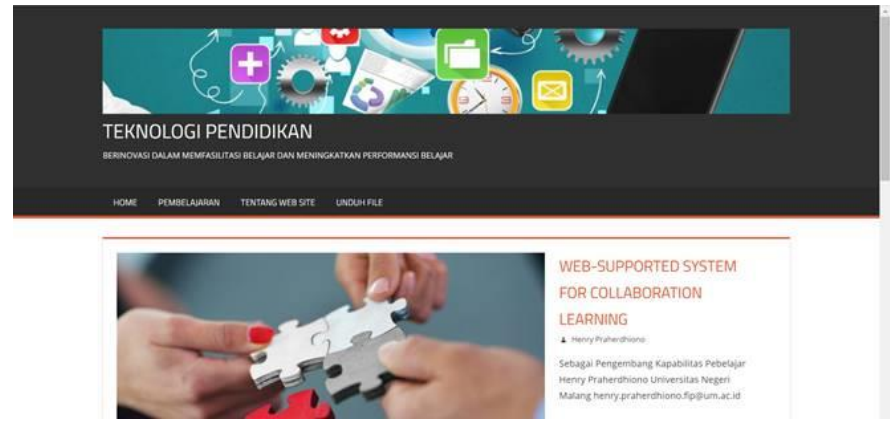

Fig. 6. MOOCs at website of teknologipendidikan.org

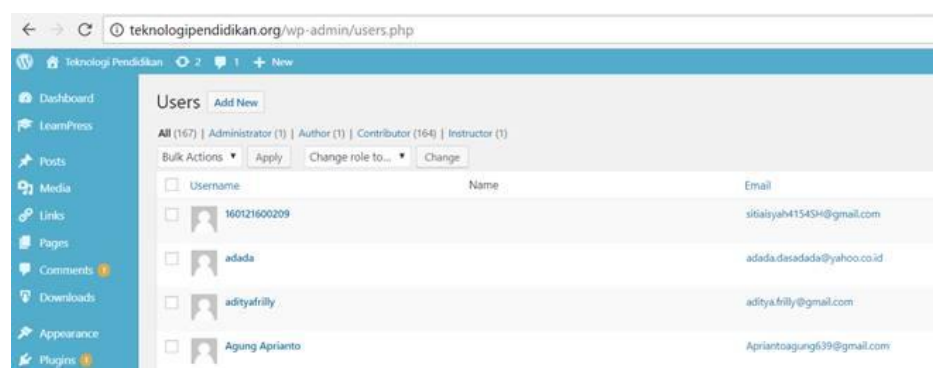

Fig. 7. List of Students as Contributors of Idea in MOOCs

Development of learning should be directed to provide a basis for thinking and acting for students. The condition of learners must be in line so that the policy of the institution. $G$ aya learn students with character innovators as the basis for managing students from every generation [29], [31]-[35]. The development of the study of learning styles shows the development of more than 70 learning styles reported in hundreds of published studies from the educational and psychological research literature. According to Coffield et al. [29], even the most studied models have not been studied carefully, so they still require special attention from researchers in particular and institutions on a macro level. The development of MOOCs as a learning ecology is a research estuary. This research produced a learning ecology in the form of website with address of teknologipendidikan.org can be seen at Fig. 6.

Learning ecology is a learning network that can be built by members who actively contribute to learning can be seen at Fig. 7. Learning ecology of UM is a strategic step to accommodate student learning activities. The next generation of students needs a form of emerging technology that can be used easily and flexibly. The technology was developed using the effectiveness approach of various technological options. The case of ecology developed by Educational Technology Department has compared the technological approach with the message design approach [36], [37]. Saettler reported that there was no significant difference between the use of educational films and classroom learning in the early 1920s [38]. The development of subsequent research is the design of comparative studies which have been applied to every new educational technology that has been used, such as tediously designed learning, television learning, computer-based learning, and more recently, various forms of Web-based e- learning. Generally all the results of media research studies used in classroom learning have no significant differences [39]-[42]. That is, in the positive thinking of learning ecology in the form of web with text, audio and video content, they are potentially used in tandem with classroom learning, because they do not cause differences in the design of messages to all learning styles of each generation of learners.

Ecology study at its core is a technology blended with learning of the emerging technology issues that have an impact on the success of online learning activities. Blended learning is a learning system that is considered the most appropriate for students. The effectiveness of online learning comparisons is better in current generations than in classroom learning [43], [44]. This case is because the online learning system is more interactive, either by itself in the form of blended learning. The system is capable of building initiatives for Gen X and Net Gen both in education, training, and professional education.

Students of UM viewed from class generation are more appropriate to utilize blended learning. This system provides development opportunities [45], [46]. In general, Gen X and Gen Net already have proficiency in online daily activities. Dziuban writes: Blended teaching and learning responds to the ability of new generations [47]. The students, born after 1980, have grown up with what they see and are interested in new technology. They are connected (mostly to one another) and proficient in the use of communication technology. This generation often sees what happens in the classroom as ancient and unattractive learning.

Analysis of support to the development of life-based learning system oi UM institution requires vision, mission, and philosophy data associated with academic implementation. The academic data and its implications will generally be obtained from the organizers, lecturers and students. Information and communication technology (ICT) in learning, is a tool that supports the management of learning [48]. Information of vision, mission and philosophy of education in UM is needed as academic script material of ICT master plan of life-based learning. Development of learning on MOOCs system requires academic script with content as follows:

- Requiring support of vision, mission and institutional commitment in developing a system of learning in general.

- Organizing the learning of the MOOCs system requires the support of Philosophy underlying Teaching and Learning using ICT,

- Implementation of the education system cannot be separated from the needs of the generation.

- Implementation of life-based learning requires alignment with ICT design of State University of Malang.

\section{CONCLUSION}

Selection of MOOCs system for students belonging to the new generation is a wise choice on the development of learners' capabilities. State University of Malang requires quick steps in building MOOCs connected with Learning Management 
System. Needs State University of Malang in the the development of MOOCs as a means of managing the generation $\mathrm{Z}$ to be an innovative generation. Fast information for learners at the State University of Malang allows students to become contributors of ideas. This condition reinforces effective learning delivery theory through online systems [43], and the theory of learning through on-line technology is an effective teaching utilizing technology [33]. The results of the MOOC's development needs in enhancing innovative capabilities provided specific progress in the development of online and traditional study environment studies as has been done by Tallent-Runnels et al. [44]. At the same time the results reinforced and clarified the findings of Moser mentioning that learners in the online environment is not only effective but more innovative [6].

Networked learning systems with the Involvement of Massive Open Online Programs (MOOCs) at the State University of Malang are a strategic priority. Open systems are the fastest and most innovative step in the field of learning with online technology. The study provides an analytical note that aims to understand that 1) the user of the learning system is a student of State University of Malang, who has the capability as an innovator, who is a technology user, 2) the most appropriate online learning ecology is the MOOCs system.

\section{REFERENCES}

[1] Á. F. Agudo-Peregrina, S. Iglesias-Pradas, M. Á. Conde-González, and Á. Hernández-García, "Can we predict success from log data in VLEs? Classification of interactions for learning analytics and their relation with performance in VLE-supported F2F and online learning," Comput. Human Behav., vol. 31, pp. 542-550, 2014.

[2] R. W. Helms, "Comparisons of parameter and hypothesis definitions in a general linear model," Commun. Stat. Methods, vol. 17, no. 8, pp. 27252753, 1988 .

[3] K. F. Hew and W. S. Cheung, "Students' and instructors' use of massive open online courses (MOOCs): Motivations and challenges," Educ. Res. Rev., vol. 12, pp. 45-48, 2014.

[4] M. Staron, "Life-Based Learning Model - A Model For Strength-Based Approaches To Capability Development and Implications for Personal Development Planning," Australian Government Department for Education Science and Training and TAFE NSW. 2011.

[5] M. E. Kenny et al., "Preparation for meaningful work and life: urban high school youth's reflections on work-based learning 1 year postgraduation," Front. Psychol., vol. 7, no. 286, pp. 1-12, 2016.

[6] S. Moser, "Linking Virtual and Real-life Environments: Scrutinizing Ubiquitous Learning Scenarios," in Digital Tools for Seamless Learning, S. N. Sad and M. Ebner, Eds. IGI Global, 2016, p. 214.

[7] R. Arends, Learning to teach. McGraw-Hill Higher Education, 2014.

[8] C. Borg and P. Mayo, Learning and Social Difference. ERIC, 2006.

[9] M. N. Cleary, K. Wozniak, C. Marienau, G. Wilbur, D. E. Tolliver, and P. Meyer, "Learning, Adults, and Competency-Based Education," in Handbook of Research on Competency-Based Education in University Settings, IGI Global, 2017, pp. 210-231.

[10] A. Margaryan, M. Bianco, and A. Littlejohn, "Instructional quality of massive open online courses (MOOCs)," Comput. Educ., vol. 80, pp. 77-83, 2015.

[11] B. Bagnol et al., "Transdisciplinary project communication and knowledge sharing experiences in Tanzania and Zambia through a one Health Lens," Front. public Heal., vol. 4, no. 10, 2016.

[12] O. Hospes, C. Kroeze, P. Oosterveer, G. Schouten, and M. Slingerland, "New generation of knowledge: Towards an inter-and transdisciplinary framework for sustainable pathways of palm oil production," NJASWageningen J. Life Sci., vol. 80, pp. 75-84, 2017.

[13] E. Serna, "Maturity model of transdisciplinary knowledge management," Int. J. Inf. Manage., vol. 35, no. 6, pp. 647-654, 2015.

[14] C. McKay, A. Keune, K. Peppler, S. Chang, and L. Regalla, "A networked vision for sharing and documenting," Open Portfolios: Maker Education Initiative, 2015. [Online]. Available: http://makered.org/wpcontent/uploads/2015/02/OPP_ResearchBrief1_ANetworkedVision_fina 1.pdf. [Accessed: 22-May-2017].

[15] H. Yaniv, "Development of Learning Resources to Promote Knowledge Sharing in Problem Based Learning," i-Manager's J. Educ. Technol., vol. 5, no. 1, p. 15, 2008.

[16] M. H. Baturay, "An overview of the world of MOOCs," Procedia-Social Behav. Sci., vol. 174, pp. 427-433, 2015.

[17] P. Hill, "Online educational delivery models: A descriptive view," Educ. Rev., vol. 47, no. 6, p. 84, 2012.

[18] A. Jacobs, "Two cheers for Web U," New York Times, vol. 162, no. 56113, pp. 1-7, 2013.

[19] A. Loya, A. Gopal, I. Shukla, P. Jermann, and R. Tormey, "Conscientious behaviour, flexibility and learning in massive open online courses," Procedia-Social Behav. Sci., vol. 191, pp. 519-525, 2015.

[20] Y. Sun, Z. Qiao, D. Chen, C. Xin, and W. Jiao, "An Approach to Using Existing Online Education Tools to Support Practical Education on MOOCs," in Computer Software and Applications Conference (COMPSAC), 2016 IEEE 40th Annual, 2016, pp. 696-705.

[21] L. Yuan and S. Powell, "MOOCs and open education: Implications for higher education," 2013.

[22] M. D. Coomes and R. DeBard, Serving the Millennial Generation: New Directions for Student Services, Number 106, Vol. 68. John Wiley \& Sons, 2004.

[23] D. C. Hampton and Y. Keys, "Generation Z students: Will they change our nursing classrooms?," J. Nurs. Educ. Pract., vol. 7, no. 4, p. 111, 2016.

[24] V. Jones, J. Jo, and P. Martin, "Future Schools and How Technology can be used to support Millennial and Generation-Z Students," in ICUT 2007 (Proc. B), 1st Int. Conf. Ubiquitous Information Technology, 2007, pp. 886-891.

[25] A. Henry, "The Changing Face of the Workforce and Intergenerational Impacts," in TAFE NSW International Centre for VET Teaching and Learning, 2006, pp. 3-8.

[26] N. Howe and W. Strauss, Millennials rising: The next great generation. Vintage, 2009.

[27] L. C. Lancaster and D. Stillman, When Generations Collide: Who They Are. Why They Clash. How to Solve the Generational Puzzle at Work. New York: Harper Collins, 2002.

[28] A. Pérez-Escoda, "Digital Skills in the Z Generation: Key Questions for a Curricular Introduction in Primary School/La competencia digital de la Generación Z: claves para su introducción curricular en la Educación Primaria," Comun. (English Ed., vol. 24, no. 49, pp. 71-79, 2016.

[29] F. Coffield, D. Moseley, E. Hall, and K. Ecclestone, "Learning styles and pedagogy in post-16 learning: A systematic and critical review." Learning and Skills Research Centre London, 2004.

[30] A. . . Yeung, Organizational learning capability. Oxford University Press on Demand, 1999.

[31] R. I. Chang, Y. H. Hung, and C. F. Lin, "Survey of learning experiences and influence of learning style preferences on user intentions regarding MOOCs," Br. J. Educ. Technol., vol. 46, no. 3, pp. 528-541, 2015.

[32] D. El-Hmoudova, "MOOCs motivation and communication in the cyber learning environment," Procedia-Social Behav. Sci., vol. 131, pp. 2934, 2014.

[33] S. Graf and T. C. Liu, "Analysis of learners' navigational behaviour and their learning styles in an online course," J. Comput. Assist. Learn., vol. 26, no. 2, pp. 116-131, 2010.

[34] F. Grünewald, C. Meinel, M. Totschnig, and C. Willems, "Designing MOOCs for the support of multiple learning styles," in European Conference on Technology Enhanced Learning, 2013, pp. 371-382. 
[35] P. J. Guo and K. Reinecke, "Demographic differences in how students navigate through MOOCs," in Proceedings of the first ACM conference on Learning@ scale conference, 2014,pp. 21-30.

[36] P. A. Machun, C. Trau, N. Zaid, M. Wang, and J. Ng, "MOOCs: Is there an app for that? Expanding mobilegogy through an analysis of MOOCS and iTunes university," in Proceedings of the The 2012 IEEE/WIC/ACM International Joint Conferences on Web Intelligence and Intelligent Agent Technology-Volume 03, 2012, pp. 321-325.

[37] M. Wang and R. Shen, "Message design for mobile learning: Learning theories, human cognition and design principles," Br. J. Educ. Technol., vol. 43, no. 4, pp. 561-575, 2012.

[38] P. Saettler, The evolution of American educational technology. IAP, 2004

[39] R. E. Clark, "Reconsidering research on learning from media," Rev. Educ. Res., vol. 53, no. 4, pp. 445-459, 1983.

[40] A. A. Lumsdaine, "Some problem in assessing instructional program," in Prospectives in programming, R. Filep, Ed. New York: Macmillan, 1963, pp. 228-262.
[41] K. W. Mielke, "Questioning the questions of ETV research," Educ. Broadcast. Rev., vol. 2, no. 6, pp. 54-61, 1968

[42] W. L. Schramm, Big media, little media. Sage Publications, 1977.

[43] R. M. Bernard et al., "How does distance education compare with classroom instruction? A meta-analysis of the empirical literature," Rev. Educ. Res., vol. 74, no. 3, pp. 379-439, 2004.

[44] M. K. Tallent-Runnels et al., "Teaching courses online: A review of the research," Rev. Educ. Res., vol. 76, no. 1, pp. 93-135, 2006.

[45] C. J. Bonk and C. R. Graham, The handbook of blended learning. Global perspectives, local designs. John Wiley \& Sons, 2012.

[46] M. J. Rosenberg, E-learning: Strategies for delivering knowledge in the digital age, Vol. 9. New York: McGraw-Hill, 2001.

[47] C. Dziuban, J. Hartman, F. Juge, P. Moskal, and S. Sorg, "Blended learning enters the mainstream," Handb. blended Learn. Glob. Perspect. local Des., vol. 195, p. 206, 2006.

[48] N. Akhtar, "ICT-Based Learning Organization Support System: Managing Continous Change," in 15th International Scientific Conference on Economic and Social Development -Human Resources Development Varazdin, 2016, pp. 45-55.

[49] 